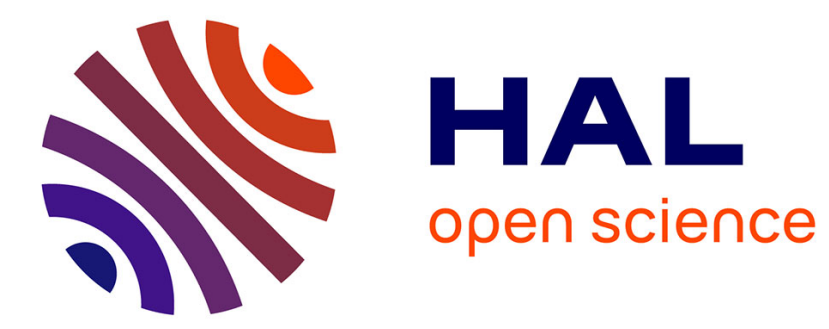

\title{
Signals and calcium waves at fertilization
}

\author{
Christian Sardet, Rémi Dumollard, Alex Mcdougall
}

\section{To cite this version:}

Christian Sardet, Rémi Dumollard, Alex Mcdougall. Signals and calcium waves at fertilization. Seminars in Cell \& Developmental Biology, 2006, 17 (2), pp.223-225. 10.1016/j.semcdb.2006.03.001 . hal-03025941

\section{HAL Id: hal-03025941 \\ https://hal.science/hal-03025941}

Submitted on 16 Dec 2020

HAL is a multi-disciplinary open access archive for the deposit and dissemination of scientific research documents, whether they are published or not. The documents may come from teaching and research institutions in France or abroad, or from public or private research centers.
L'archive ouverte pluridisciplinaire HAL, est destinée au dépôt et à la diffusion de documents scientifiques de niveau recherche, publiés ou non, émanant des établissements d'enseignement et de recherche français ou étrangers, des laboratoires publics ou privés. 


\title{
Editorial
}

\section{Signals and calcium waves at fertilization}

\author{
Christian Sardet*, Rémi Dumollard, Alex McDougall \\ Laboratoire de Biologie du Développement, UMR 7009, CNRS/Université P et M Curie, \\ Station Zoologique, Observatoire, Villefranche sur Mer 06230, France
}

Available online 16 March 2006

\begin{abstract}
The study of sperm egg interactions and the signals they trigger, have made remarkable progress from the time of the seminal discovery of calcium waves 30 years ago. In this special issue of Seminars in Cell and Developmental Biology, 3 short pieces and 10 expert reviews survey this recent past and brings us up to date with current developments in this fertile field. Jaffe, Steinhardt and Whitaker recall the historical years while Miyazaki, Dumas, Rubinstein, Swann, Fissore, Sato, Foltz, Stricker, and their co-authors bring us up to date with current developments in sperm egg interaction, egg activation and calcium signalling. Dumollard, Duchen and Sardet and Ducibella, Schultz and Ozil deal with the pleiotropic consequences of stereotyped calcium signals from the cytoplasmic and cortical reorganizations they trigger including the stimulation of mitochondrial respiration, cell cycle regulation, the activation of protein synthesis, and subsequent developmental events. A list of interesting web sites giving access to video archives of fertilization and calcium waves is also provided.
\end{abstract}

(C) 2006 Elsevier Ltd. All rights reserved.

\section{A historical perspective}

Fertilization has intrigued researchers ever since the 19th century when Thuret, Fol and Hertwig described the encounter and fusion of sperm and egg in algae and echinoderms of the Mediterranean coast. These observations led to a gradual understanding of the central roles played by nuclei, centrosomes and chromosomes in the life of the cell.

\section{The discovery of calcium signals}

At first there was Loeb who understood that sperm transmitted a factor to eggs and that ions were key to egg activation. Heilbrun followed by Mazia speculated that changes in calcium levels constituted the main switch but they did not have the means to measure free calcium in living cells. When Shimomura extracted the calcium sensitive protein aequorin from jellyfish and when sensitive photomultipliers became available, the stage was set for measuring free calcium in cells. And it was first measured in large egg cells of sea urchins and much larger eggs of fishes activated by sperm or by artificial means. Less than a decade of research starting in the 70s showed unequivo-

\footnotetext{
* Corresponding author. Tel.: 4937637 71; fax: 493763792

E-mail address: sardet@obs-vlfr.fr (C. Sardet).
}

cally the central role played by calcium during fertilization and in cell signalling in general.

In this special issue, Richard Steinhardt recalls how in 1976 he measured the calcium increase in sea urchin eggs in Berkeley where Dan Mazia and David Epel had led the way [1]. Lionel Jaffe tells of the historical discovery of the calcium wave that traversed the Medaka fish egg during exciting experimental sessions with physicists at Yale [2]. Michael Whitaker, who was first to look at the mechanism of egg activation from the perspective of secondary messengers, recounts injecting InsP3 in sea urchin eggs at University College, London [3]. He went back to his notes of 1984 to find that this was the year he adopted the apple MacIntosh as his notebook. This was the beginning of the digital age.

Thirty years have passed and calcium signals and waves discovered in eggs are now known to be universal signals not only in all animal cells, embryos and tissues but also in plants. Shun Miyazaki, who first observed in the early 1980s that fertilization in hamsters triggered repetitive changes in egg potential and calcium signals, reviews the evolution of research on calcium wave initiation and propagation [4]. Miyazaki covers all the landmark events, brings us up to date with recent progress in the role of secondary messengers and reviews the saga of the sperm factor in animal fertilization. Calcium also plays multiple roles in the intricate processes of fertilization in plants and algae, a complex subject Christian Dumas and Thierry Gaude review in detail [5]. 


\section{Sperm-egg binding and fusion}

Of course sperm have to first bind to then fuse with the egg to complete the job of injecting their haploid DNA content into the egg cytoplasm. Shortly after fusion in mammals (and likely other species also) sperm also provide the egg with an activating factor (the sperm factor), thus neatly linking injection of paternal genes and the activation principle. Eric Rubinstein and his colleagues describe the progress made in the field to identify those proteins involved in sperm-egg binding and fusion [6]. Some of these proteins are on the sperm, others are on the egg. To briefly summarize some of the elegant work (mostly with knockout mice) we first learn about Izumo, a protein with a single Ig domain found on sperm that is required for sperm-egg fusion. On the egg side, a role for GPI-anchored molecules has been shown, and the tetraspanins CD9 and CD81 appear to both be required since only the double knockout mice are infertile.

\section{Sperm factor and repetitive calcium waves}

Egg activation requires that the sperm triggers a local increase in free calcium in the cortex and/or at the site of fusion with the egg membrane. Working with sea urchin homogenates and mammalian eggs and sperm Karl Swann, Anthony Lai and colleagues [7] describe how they discovered that mammalian sperm contain a special phospholipase particularly sensitive to calcium (PLCZeta), which has all the characteristics of the long sought sperm factor or "catalytic substance" first proposed by Jacques Loeb more than a century ago. The "fishing season" is thus finally closed in mammals, however, as discussed by many of the reviewers in this issue, it is very much still open season in non-mammalian species where a different activating factor/mechanism is likely employed.

In the eggs of mammals, ascidians, echiurean worms, molluscans, and nemerteans sperm-triggered calcium signal takes the form of calcium oscillations that can last for less than an hour, as in invertebrate eggs, to several hours, as in the mammals. By the late 1980s it was discovered in ascidians that all these calcium oscillations were in fact waves triggered by cortical pacemakers. This and other aspects of cytoplasmic and cortical reorganizations are discussed by Steven Stricker who stresses the essential role of endoplasmic reticulum (ER) microdomains in triggering, propagating and modulating calcium waves in line with cell cycle phases [11]. In species fertilized before meiosis completion, repetitive calcium waves propagate from ER-rich cortical pacemakers until the egg is driven out of the meiotic cell cycle. Interesting questions such as; how do you maintain activity of the sperm factor thus ensuring egg activation?; how is the sperm factor inactivated once the egg has exited meiosis? are addressed in the review by Raphael Fissore and colleagues [8].

\section{The search for a universal mechanism of egg activation}

In the amphibian Xenopus things are a little different. Although fertilized in MII of meiosis as mammals, only a single calcium wave is triggered by sperm. In the review by Ken-ishi
Sato, Yasuo Fukami and Bradley Stith the idea that the activation of Xenopus eggs by sperm may be due to binding of the sperm to an egg receptor rather than through delivery of a diffusible sperm factor is discussed [9]. The chapter describes work that has lead to the proposal that egg Src kinase is part of the signalling cascade. In the chapter by Kathy Foltz and colleagues we learn that echinoderms too are thought to use egg Src kinase for activation [10]. Ascidians-urochordate organisms at the basis of the vertebrate line-are also thought to use Src kinase, which is interesting since there is also evidence for a sperm factor in ascidians, thus combining the sperm factor fusion-based mechanism operating in mammals with the Src kinase mechanism operating in Xenopus and echinoderms. Only time and more research will tell whether multiple mechanisms operate at fertilization in different species and what their details are.

\section{The role of Calcium signals and waves}

Increasing free calcium concentration $20-100$-folds in the egg has pleiotropic effects on a multitude of enzymatic and metabolic processes, polymerization and depolymerization reactions, fusion of cortical vesicles or fragmentation events such as the fragmentation of ER network observed in echinoderm eggs at the peak of calcium rise. The role of repetitive calcium waves is more intriguing. Rémi Dumollard, Michael Duchen and Christian Sardet describe how, as in somatic cells, periodic calcium signals in eggs are "decoded" by mitochondria and participate to the activation of metabolism [12]. In turn, mitochondria modulate calcium oscillations. The intriguing possibility that major developmental information is encoded in the spatial and temporal pattern of meiotic calcium waves, which in mammals and ascidians propagate from the vegetal pole, is examined by Tom Ducibella, Richard Schultz and Jean Pierre Ozil [13]. They review evidence that calcium signals are involved in cell cycle regulation, RNA recruitment and protein synthesis.

\section{Economic and social impacts of this research}

As pointed out by several of the authors, there could be benefits some day for assisted reproduction techniques in humans when procedures like ICSI fail to have a positive outcome. Those interested in sperm-egg interactions are also very conscious of the potential of a male contraceptive pill. Success rate of cloning and parthenogenetic development are likely dependant on mimicking the frequency, amplitude and directionality of calcium signals. Finally, it has been proposed that the ethical issue of therapeutic cloning may be sidestepped by producing ES cells from parthenogenetic embryos in conjunction with nuclear transfer and artificial activation, perhaps by sperm factor.

\section{A Web archive of calcium waves and fertilization}

1. http://www.twmu.ac.jp/Basic/physiol2/miyazaki_lab/ calcium_wave/index.html

S. Miyazaki laboratory site displays beautiful calcium oscillations and waves in mouse eggs lasting for several hours 
after fertilization. Waves are accompanied by slight cytoplasmic movements. The site also shows calcium waves induced by injection of sperm extract or injection of a spermatozoon into the egg (ICSI).

2. http://clapham.tch.harvard.edu/video.html

David Clapham laboratory site. Spectacular spiralling calcium waves can be triggered in the large egg of the amphibian Xénopus through manipulation of muscarinic receptors and uncaging of Caged IP3 or GTPgammaS.

\section{3. http://www.bioclips.com}

This site initiated by Christian Sardet features many multimedia documents (BioClips) which can be downloaded for teaching or just fun. "Sparks of Life" recounts the discovery of egg calcium waves and sperm factors including historical sequences recorded by Lionel Jaffe and his colleagues in Medaka eggs. See also "Multiple Calcium Waves Pacemakers in a Single Cell".

\section{4. http://biodev.obs-vlfr.fr/recherche/dougall/}

and

http://biodev.obs-vlfr.fr/recherche/biomarcell/ascidies/

Anim-calcium.html

The BioDev and BioMarCell laboratory sites in Villefranche sur Mer display many films of fertilization in ascidians, sea urchins and ctenophores and of repetitive calcium waves in ascidians.

5. http://petrus.ncl.ac.uk/downloads.html

http://petrus.ncl.ac.uk/urchins/movies3.html

The Whitaker and Petrus site has a large archive of calcium signals in eggs and embryos of sea urchins and Drosophila.

6. http://carbon.cudenver.edu/ bstith/waverot.htm

The Stith laboratory displays films of fertilizing Xenopus eggs traversed by surface waves triggered by the fertilization calcium wave.
7. http://www.molbiolcell.org/cgi/content/full/9/7/1609

A link to Marc Terasaki's films in "Imaging of echinoderm fertilization".

8. http://www.stanford.edu/group/Urchin/

This educational site created by David Epel and Chris Patton has a good introductory series of cartoons and schematic movies of fertilization and early development in sea urchins.

\section{References}

[1] Steinhardt R. Three stages (and a dividend) on my personnal road to $\mathrm{Ca}^{2+}$ activation at fertilization. Semin Cell Dev Biol 2006;17(2): 226-8.

[2] Jaffe L. The discovery of calcium waves. Semin Cell Dev Biol 2006;17(2):229.

[3] Whitaker M. IP3 Semin Cell Dev Biol 2006;17(2):230-2.

[4] Miyazaki S. 30 years of calcium signals at fertilization. Semin Cell Dev Biol 2006;17(2):233-43.

[5] Dumas C, Gaude T. Fertilization in plants: Is calcium a key player? Semin Cell Dev Biol 2006;17(2):244-53.

[6] Rubinstein EA, Ziyyat JP, Wolf Le Naour F, Boucheix C. The molecular players of sperm-egg fusion in mammals. Semin Cell Dev Biol 2006;17(2):254-63.

[7] Swann K, Saunders CM, Rogers NT, Lai FA. PLCל(zeta): A sperm protein that triggers $\mathrm{Ca}^{2+}$ oscillations and egg activation in mammals. Semin Cell Dev Biol 2006;17(2):264-73.

[8] Lee B, Sook-Young Y, Fissore R. Regulation of Fertilization-Associated $\mathrm{Ca}^{2+}$ Oscillations: a multi-pronged approach. Semin Cell Dev Biol 2006;17(2):274-84.

[9] Sato K, Fukami Y, Stith BJ. Signal transduction pathways leading to $\mathrm{Ca}^{2+}$ release in a vertebrate model system: lessons from Xenopus eggs. Semin Cell Dev Biol 2006;17(2):285-92.

[10] Townley IK, Roux MM, Foltz KR. Signal transduction at fertilization: the $\mathrm{Ca}^{2+}$ release pathway in echinoderms and other invertebrate deuterostomes. Semin Cell Dev Biol 2006;17(2):293-302.

[11] Stricker SA. Structural reorganizations of the endoplasmic reticulum during egg maturation and fertilization. Semin Cell Dev Biol 2006;17(2):303-13.

[12] Dumollard R, Duchen M, Sardet C. Calcium signals and mitochondria at fertilization. Semin Cell Dev Biol 2006;17(2):314-23.

[13] Ducibella T, Schultz R, Ozil JP. Role of calcium signals in early development. Semin Cell Dev Biol 2006;17(2):324-32. 